\title{
Unearthing New Dimensions of Black "Womanism": Poetic Resistance and the Journey from Absence to Self-Representation
}

\author{
Mounir Ben Zid* \\ Sultan Qaboos University \\ Corresponding Author: Mounir Ben Zid, E-mail: mounir@squ.edu.om
}

\section{ARTICLE INFO \\ Article history \\ Received: September 12, 2019 \\ Accepted: November 16, 2019 \\ Published: December 31, 2019 \\ Volume: 10 Issue: 6 \\ Advance access: November 2019}

Conflicts of interest: None

Funding: None

\section{Key words:}

White Feminism,

Black "Womanism",

Poetic Resistance,

Visibility,

Self-Representation

\begin{abstract}
Significant headway has been made in investigating white feminist monolithic strategies and exploring how black females have suffered from patriarchal ideology and stereotyping, and how they were placed in an inferior position and treated as slaves and sexual machines. In research conducted on women of color, however, little attention is paid to black females' new vision of black "womanism" and its means of struggle. With this in mind, the aim of this study is twofold. First, the goal is to elucidate why black women were victims of white prejudice, despotism, and patriarchal practices. Second, we wish to demonstrate how black females set themselves free from racial ideology and Western hegemony by opting for poetic resistance to achieve hypervisibility, seek their own spirituality, worship their black female deities, restore the joy of their motherhood, and assert their identity. The findings yielded by this research provide support for the key argument that black "womanism" and poetic resistance are the means of self-representation and liberation from Eurocentric, dehumanizing, and exclusionary ideology to repossess one's erased self.
\end{abstract}

\section{INTRODUCTION}

Early theorists and practitioners of feminist literary criticism were white feminists who, by adopting a monolithic and Eurocentric ideology, perpetuated the silencing of black women and excised dark-skinned female writers from the mainstream literary tradition. Mainstream feminist advocates, together with black scholars, tended to treat women of color as "the mules of the world," gave little or no place to the writings of women of color, and excluded the work of black women from anthologies and critical studies. Over the past fifty years, a large body of research on the contours of black women has been conducted, whereby most authors have viewed it as grounded in a monolithic white ideology. Among the most flagrant examples of this trend is Zora Neale Hurston who, in her novel Their Eyes Were Watching God, vehemently attacks white hegemonic strategies and monolithic practices. To signify the abuse of African American women throughout history, Hurston's protagonist Janie Crawford acknowledges:

Honey, de white man is de ruler of everything as fur as Ah been able tuh find out. Maybe it's some place way off in de ocean where de black man is in power, but we don't know nothin' but what we see. So de white man thrown down de load and tell de nigger man tuh pick up it up. He pick it up because he have to, but he don't tote it. He hand it to his womenfolks. De nigger woman is de mule uh de world so fur as Ah can see. (Hurston, 2008, p. 14)

Silencing these uprooted voices has been an effective way to prevent deracinated creatures from building an identity, unless it was in accordance with the dictates of their oppressors. Despotism, cruelty, and subjection from the primeval years of bondage to those of colonization have created a massive load under which black women all over the world have attempted to survive. Tyranny in its various forms has placed black women in an inferior position, if not in an invisible stance, as being victims of white patriarchal prejudices and stereotypes has literally transformed black women into specters, while being objectified as sexual machines and exploited as laboring engines in the plantations. Within such framework, black femininity has been undervalued by the black masculine community, which has resulted in furthering the devastating feeling of otherness.

Yet, despite a plethora of critical studies and the considerable number of black female writers and critics from every continent who have shown concern for the traditional, Eurocentric, and monolithic perspective on women of color, scant attention has been given to the ways in which black feminist 
activists have developed a new vision according to which the desire to seize identity by breaking the conspiracy of silence and forming different versions of self represents the main tool for resisting white feminist discourse and improving black women's status. In parallel to these novel critical insights, women of color have also extended their enterprise in attributing justice to the literary productions of black female authors and defending the view that black women have their own literary past that must be granted equal consideration.

To understand the true nature of black feminism, additional studies are needed to unearth new dimensions of black "womanism" and explore unfamiliar means of darkskinned women's means of struggle, the most efficient of which is poetic resistance to embark on a journey "from erasure to presence, from margins to the centre, from absence to self-representation, from mute voices to interventional speech acts - from histories to 'her' stories" (Purkayastha, 2012, p. 13). Taking shape out of her invisibility and determined to speak "herstory," black feminism has rejected monolithic feminist theories, redefined black feminism, and defended a new type of "womanism" at the core of which lies "Black women-identification," as Bethel (1982) puts it:

Black feminist literary criticism . . . is most simply the idea of black women seeking their own identity and defining themselves through bonding on various levels-psychic, intellectual as well as physical-with other black women. . . . Black women-identification is black women not accepting male-including black male - definitions of femaleness or black womanhood. (p. 4)

On these grounds, in this work, white feminism and its hegemonic ideology, strategies, and practices are examined before shifting focus to the ways in which women ultimately gave way to their repressed voices in the very matrix of language. This need for expression was a result of the impact of harassment and the inability to take action against the chain of physical, social, political, economic, and cultural offenses. In such context, poetry has become the main genre of the female "other" through which she inscribes the elements of femininity she has been forbidden to express in everyday life.

Another founding premise of the present investigation is to shed light on the notions of identity, motherhood, and spirituality. It is within this kind of rhetoric that the assertion of identity stands as a crucial weapon through which women uphold their selfhood, so that the smothering of the white cruel voices and injustice serves as a concrete process of becoming.

The paper will commence by examining how the resuscitation of mothering and motherhood unmasks the complex figure of the black mother in defining the social environment she has been confronted with. While attempting to highlight black women's artistic experience inherited from several generations, spirituality will be revealed to be a fundamental ingredient in procuring black women's liberation and selfhood. By undertaking analysis of black female lyrics all over the world and throughout different eras, a wider range of feminine voices and forms of poetic resistance deriving from Africa, West Indies, the Indian sub-continent, the United States, Great Britain, and Australia will be presented.

\section{White Feminist Eurocentric Ideology}

White feminism is a movement that has traditionally ignored and undermined race and ethnicity (Stasiulis, 1992), which has led to the erasure by white women of black women's lives and literary works. Condemning such deliberate dismissal of black women and referring to it as "white silence," the black feminist Audre Lorde (2007) argues:

The history of white women who are unable to hear Black women's words, or to maintain dialogue with us, is long and discouraging .... . I feel you do celebrate differences between white women as a creative force toward change, rather than a reason for misunderstanding and separation. But you fail to recognize that, as women, those differences expose all women to various forms and degrees of patriarchal oppression, some of which we share and some of which we do not . .

Within the community of women, racism is a reality force in my life as it is not in yours. (pp. 66-67)

In this discourse, white Eurocentric feminism manifested itself in various ways, ranging from patriarchal ideology to the exclusion of black females.

\section{Patriarchal Ideology and Stereotyping}

What gave American chattel slavery its uniquely oppressive character and power was its insistence that enslavement was a natural and proper condition for particular races of people. Reinforced by theories of racial difference promoted by philosophers like Hegel, Kant, and Hume, most Europeans and Americans assumed that physical features and external differences between blacks and whites signified inherent disparities in character, intelligence, morality, and spirituality. The system of chattel slavery was designed to prevent Africans and their descendants from building a new identity, since the intention of bondage was to create in male and female slaves a complete sense of alienation and an absolute dependence on the master's will. In a similar vein, Gloria T. Hull and Barbara Smith comment on the triple burden of class, gender, and race, and argue that the "condition of Blackness and femaleness by whites is seen in terms of 'thinking like a woman' and acting 'like a nigger.' . . . Therefore, the most pejorative concept in the white/male view would be that of thinking and acting like a "nigger woman"' (as cited in Hayes, 2000, p. 20).

For instance, there were many African American women writers in the nineteenth century who were not well known due to limited publishing and distributing opportunities. Harriet Jacobs (2013) was among the earliest famous African slaves who authored their narratives and challenged conventional ideas about slavery and freedom. In her "Incidents in the Life of a Slave Girl," Jacobs demonstrates how sexual exploitation contributed to slavery and the oppression of black women.

The invisibility of black women speaks of the separate narrative constructions of race, gender, and class within racial discourse where the subject is white, as well as in 
gendered discourse, where the subject is male. It is due to such ideological blind spots that black women occupy the most critical place.

Historically, the plantation economy has produced a multi-racial society in which black women sought a route to a better life by passing "as white." They were seen as a threat to European women who were incarcerated in colonial houses and subjected to Victorian social conventions. Thus, erotic rivalry under colonialism and slavery was likely to make these women enemies rather than friends and colleagues. Moreover, such social structure allowed Western men to transfer their lust and sexual hang-ups onto black women, "otherizing," iconizing, and abusing them so that black women are perceived as fetishistic objects of lust rather than individuals. This patriarchal transfer of libidinous energy can be explained by classifying the black woman as an object for a male gaze that is paradoxically being scrutinized for causing a carnal response and standing for "a synecdochic machine reproducing an originary fantasy of the original site that entices imperial penetration and conquest" (Emberley, as cited in Marchand \& Parpart, 1995, p. 113).

As further evidence of the white hegemonic practices, in her essay "Women, Race and Class," Davis (1981) provides images of the lynching white institution which is complemented with the rape of black women. This foregrounds the idea that the black body is central to the political strategy that cannot be separated from the social reality displaying racism and perpetrating the perception of the black body as vulnerable to whiteness.

Similarly, Fanon (1952) contends that the reason behind "racial" encounters in everyday life is the familiar politics of sex, race, and desire, which is essentially an extension of the white colonizers" "desiring machine," since the fantasies of the Western imagination stand as a historical social production. As Fanon puts it, "Her blackness is fine. The blackness of her skin, the blackness of her mind. Her beauty cannot be measured with standards of a colonized mind" (p. 113).

Along the same lines, in "The Fabulous Adventures of the Mahogany Princesses," Gargi (1998) depicts the colonizing gaze upon the little princesses. In this story, the narrator displays physical endurance through which the act of looking becomes the way to the concretization of the white men's dream and "narcissistic fantasies." In Gargi's view, the colonizer is "the scopic master, squashing everything jealously into dimensions . . . to balance the thrill between feeling bad and feeling good" (p. 168). Within this context, the princesses go through many adventures and are left with deeply imbedded injuries and plenty of pain. For them, memory no longer has a significant shape, as the skin has become the main thing they represent and the way in which they imagine themselves, since feeling better depends on altering the already established visual images.

With regard to the constructs of feminine attractiveness, black women hold a different racialized space from that occupied by their white counterparts. Not only has female beauty been constructed to objectify women, but is also based upon dominant definitions of beauty that carry heavy consequences for black women. The historical association of whiteness as a criterion of beauty has been internalized by both black men and women. This negation of the beauty of black hair texture, dark skin, and shape of lips and noses, has had profound impact on black women and their attempts to appear attractive to males. Contemporary black writers like Harry Cleaver have examined the reasons behind black men's rejection of black femininity:

There is a softness about a white woman, something delicate and soft inside her. But a nigger bitch seems to be full of steel, granite-hard and resisting. I mean I cannot analyze it, but I know that the white man made the black woman as a symbol of slavery and the white woman the symbol of freedom. Every time I embrace a black woman, I am embracing slavery, and when I put my arms around a white woman, well, I am hugging freedom. (as cited in Mirza, 1998, p. 115)

\section{Exclusion of Black Females from the White Feminist Movement}

Many black and post-colonial women have argued that feminism is a largely white Westernized construct which tends to ignore the daily experiences of race and hardship and concocts particular patterns of motherhood, sexual, and gendered relationships or women's ability to speak out critically. Accordingly, the triple oppression of gender, race, and class can be understood as the denominator determinant of black women's lives.

Moreover, black women's simultaneous subjectivation to the oppression of patriarchy, class, and race is the prime reason for not employing parallels that render their position and experience not only marginal but also invisible. In this respect, Suleri (1992) suggests that "only a Black can speak of a Black, only a postcolonial sub-continental feminist can adequately represent the lived experience of that culture" (p. 27). She also identifies two patterns that privilege women's writings, one of which connotes polyphony, multi-vocality, and plurality of voices, while the other highlights intimate, private, and inspired utterances. Both modes of writing can be adopted to pronounce competing claims and to witness common concerns.

On a similar note, Armos and Pramar (2005) maintain that mainstream feminist theory does not speak of the experience of black women, and those that attempt to do so tend to adopt a racist perspective and Eurocentric reasoning, according to which black women are exposed as "victims of barbarous, primitive practices in barbarous primitive societies" (p. 48). It must be emphasized here that much feminist work is rooted in the belief that it is only through the development of Western industrial capitalism that the potential for the liberation of women can increase. However, this does not explain the existence of "feudal residues," such as foot binding and clitoridemy, or "traditionalism" such as polygamy in the United States, where economic and industrial growth is at its peak.

Another strategy through which women of color are marginalized and excluded from the white feminist movement is the idealization of anthropological works in which black women are treated as subjects of exotic comparison. Such 
lack of awareness is the reason for the failure of academic feminists to recognize difference as a crucial power for Third World women, without overlooking how women's peace movement has remained largely white and still excludes any understanding or sensitivity to the situation of black females.

As far as difference seems to encapsulate the triple burden of race, class, and gender, the development of black and Asian women's feminism has started to receive greater attention in the postmodernist debate. For example, Susheila Nasta is wondering whether being feminist "involves a further displacement or reflects an implicit adherence to another form of imperialism" (as cited in Wisker 2000, p. 26), whereas Mohanty (2003) delineates in her essay "Cartographies of Struggle" the urgency and necessity of revising the feminist theory within a cross-cultural framework. Mohanty also suggests the idea of an "imagined community" of Third World oppositional struggles. Such a proposal, in her view, is efficient since it calls for a political struggle, rather than biologically- or culturally-based alliances.

As the discussion presented above indicates, women of color should reconsider their way of organization to address and face the totality of oppression. They must also realize that prioritizing one aspect of oppression to the exclusion of others is not an option, as the realities of day-to-day lives make it imperative for black women to take into account the simultaneous nature of oppression and exploitation. In view of this complex reality, only a synthesis of class, race, gender, and sexuality can contribute to the development of black feminism and its progress toward women's liberation.

\section{Black "Womanism" and Poetic Resistance}

Mainstream black feminism-or rather "womanism"-has emerged as a parallel non-monolithic movement that is distinct from white feminism. The latter aspires to subvert the longstanding gender stereotypes that dominate and subordinate women and attack the theoretical constructions of the white feminist theory as being imperialist, racist, Eurocentric, and exclusionary. In contrast, condemning the erasure by white women of black women's lives and qualifying "white silence" as white violence, black "womanism" emerged as a way of living for black women who refused to identify with the white feminist movement, encouraging both black women and men to participate. This more inclusive movement places a high value on community, race, culture, and loving women, as the literary author and activist Alice Walker (1983) describes it in her book "In Search of Our Mothers' Gardens: Womanist Prose":

WOMANIST 1. From womanish. (Opp. of "girlish,” i.e. frivolous, irresponsible, not serious.) A black feminist or feminist of color .... Usually referring to outrageous, audacious, courageous or willful behavior .... . Interested in grown up doings. Acting grown up. Being grown up . . . In charge. Serious. 2. Also: A woman who loves other women, sexually and/or nonsexually. Appreciates and prefers women's culture, women's emotional flexibility (values tears as natural counterbalance of laughter), and women's strength . . . . Committed to survival and wholeness of entire people, male and female .Traditionally a universalist [and] capable, as in:
"Mama, I'm walking to Canada and I'm taking you and a bunch of other slaves with me." Reply: "It wouldn't be the first time." 3. Loves music. Loves dance. Loves the moon. Loves the Spirit. Loves love and food and roundness. Loves struggle. Loves the Folk. Loves herself. Regardless. 4. Womanist is to feminist as purple is to lavender. (pp. xi-xii)

In this vein, black "womanists" felt they were called on to defend a new type of black feminism and reject the Eurocentric images that support hegemony. Black "womanists"from Anna Julia Cooper and Ida Wells-Barnett through bell hooks, Patricia Williams, and Alice Walker-have explored a creative and pragmatic response to the circumstances that prevented black women from embarking on a journey from absence and erasure to self-representation.

Thus, black women around the world have employed various tools of resistance to heal from centuries of abuse and fight against white racism and Western hegemony. In addition to the traditional way of resisting white hegemonic discourse, women of color have also developed other coping styles and strategies of poetic resistance to break their silence and achieve hypervisibility, most notably the revival of spirituality and the worship of a female deity, the resurrection of motherhood, and the assertion of identity.

\section{The Revival of Spirituality and the Worship of Black Female Deities}

While feminism in the late 1960 s and 1970 s tended to focus on material and social issues, ranging from unequal pay and employment opportunities to sexual harassment, many contemporary black feminists are giving increasing attention to women's spiritual issues. This shift was prompted by the recognition that feminist spirituality does not merely replace a female godhead for a male, but rather reappraises larger issues of faith, belief, community, and healing within the specific cycle of women's lives. Denied opportunities to acquire material wealth as well as the ownership of their own bodies, black women have been compelled to face their own interior space where mastering their spirits cannot be refuted. In addition, even though black women have always displayed some religious fervor, they have never enjoyed religious authority. Through spiritualism, however, women of color have been able to transmute their inner strength into an external force by glorifying the principle that this world and the hereafter are interconnected and that there exists a harmony between the physical and the spiritual.

Accordingly, black women have shaped personal experiences into oral traditions, religiously artistic poems, prose, meditations, and letters. In fact, the African indigenous, matriarchal, and spiritual traditions have survived in black America through the writings of Phillis Wheatley, who admitted her absolute dependence on the grace offered by God and emphasized the role of the female deity in creating and sustaining Earth. While searching for her soul, Wheatley worships the female Goddess and "imperial queen" who has become the basis of feminist spirituality through an apocalyptic vision. She gives a voice to black women who can enjoy a new feeling of relief by worshiping the 
"Dark Mother" of Africa whose divine presence procreates mystical wisdom and thereby connotes a sense of empowerment:

Thy various works imperial queen, we see,

How bright their forms! How deck'd with pomp by thee!

To tell her glories with a faithful tongue,

Ye blooming graces, triumph in my song.

Imagination! Who can sing thy force?

Or describe the swiftness of thy course?

Soaring through air to find the bright abode,

The imperial palace of the thundering God,

We on thy pinions can surpass the winds,

And leave the rolling universe behind:

From star to star the mental optics rove.

There in one view we grasp the mighty whole,

Or with new worlds amaze th' bounded soul.

(as cited in Carretta, 2004, p. 64)

Another notable example of celebrating the "Black Madonna" is found in Maya Angelou's (2015) poem "Woman Me," where the image of a Goddess prevails, venerating the sublimity of the almighty's resurrection in people's lives. Here, the poet implicitly charges men with the centuries of pain and suffering they inflicted on women, and accuses them of misinterpreting biblical texts and distorting the teachings of Christ. It is in these texts, according to Angelou, that black women can discover the truth about the real love of God and supernatural forces in the Universe. It is also through the "Blessed Virgin Mary" that faith is interpreted properly and the boundaries of the church are transgressed, bringing joy to the souls of black women:

Your smile, delicate

Rumor of peace.

Deafening revolutions nestle in the

Cleavage of

Your breasts

Beggar-kings and red-ringed priests

Seek glory at the meeting

Of your tights

A grasp of lions, a lap of lambs.

Your laughter, pealing tall

Above the bells ruined cathedrals

Children reach between your teeth

For charts to live their lives

A stamp of feet, a bevy of swift hands. (11. 1-14)

In view of this, spirituality and faith have become integral elements of women's everyday life practices, since they connect different realities and encompass a wider range of experiences, without valorizing renunciation of one's ambition and hope. Gwendolyn Brooks exemplifies this vision in "Religion" by stating:

At home we pray every morning, we

Get down on our knees in a circle

Holding hands, holding love,

And we sing hallelujahThen we go into the world. (as cited in Martin \& Davidson, 1995, p. 285)

Notwithstanding the fact that freedom and escape of black women through spirituality was invisible and directed inward, it was also visible and projected externally, since women of color could speak and challenge authority, and have made their own places on Earth in their spiritual world. In "Though I am Weak and Tired Now," Mettica describes how Indian women preserve practices wherein the body, emotions, mind, and spirit are inextricably intertwined. Through such a bodily and spiritual exercise, and in her teaching on the noble truth of old age, the poet highlights the religious belief that God uses suffering and pain to instruct his Earthly creatures and honor the powerful impact of the female deity in rescuing women from defeat and collapse:

Though I am weak and tired now,

And my youthful step long gone

Leaning of this staff

I climb the mountain peak,

My cloak cast off, my bowl overturned,

I sit here on this rock,

And over my spirit blows

the breath

Of liberty

I've won, I've won the triple gems

The Buddha's way is mine.

(as cited in Urubshurow, 2008, p. 69)

There is no doubt, therefore, that during centuries of patriarchal control, women of color have negotiated various layers and levels of existence, producing forms of poetic resistance that are often unnoticed or relegated, namely speaking their own way, defining their own truth, extolling their pious creed, and creating their own female deities.

\section{The Resuscitation of Motherhood}

Maintaining black women as the "Other" has provided an ideological justification for race, gender, and class oppression. As a punishment, black women have long been plagued with a variety of negative images. Portraying women of color as "stereotypical mammies," "matriarchal welfare recipients," and "hot mammas" has been essential to the political and economic system of domination in furthering black women's oppression.

In "Black Feminist Thought," Patricia Hill (2000) argues that the elite white men and their representatives must be in a position to manipulate appropriate images of black women by exploiting already existing figures. These controlling symbols are used to justify racism, sexism, and poverty as a natural and inevitable product of everyday life. Within this hegemonic frame, domination implies further attempts to objectify the subordinate group, sometimes to the extent that completely erases the "Other." Accordingly, challenging these controlling icons has long been a central matter in black feminist thought.

From this perspective, the work of Gwendolyn Brooks $(1945,1949)$ challenges traditional and feminist constructions of the woman writer and the differences between male and female writings, whereby the former is perceived as naturally procreative, whereas the latter is by nature infanticidal. Much of Brooks' poetic achievement represents her attempts to articulate and unmask the unvoiced and invisible place of the black woman, and particularly the black mother in a world that has failed to acknowledge her existence. 
By way of illustration, in "A Street in Bronzeville," Brooks (1945) revisits the black mammy figure of the white literary tradition and contrasts it with the idealized figure of the black mother as a vital element in the black literary tradition. Focusing on the delicate subject of abortion in this poem, Brooks refuses to simplify or sentimentalize the complexity of the mother's emotions. In addressing her "dim killed children," she controls her emotions and chooses to kill her children as the ultimate yet unbearable alternative to life of oppressions of poverty and race, as well as the violations of the social order. As a sign of the black mother's powerlessness in an oppressive social system, abortion is both a perverse form of motherhood and, paradoxically, a manifestation of maternal power. Hence, the black woman, and more particularly the black mother, has become the site of social rupture where the contradictions of the American culture are located and exposed.

In "Annie Allen," an epic of black womanhood, Brooks (1949) reasserts her pride in moving toward self-definition and a new social consciousness of the black mother:

My hand is stuffed with mode, design, device.

But I lack access to my proper stone.

And plenitude of plan shall not survive. (p. 204)

Placing emphasis on the mother's frustration, pain, and lack of political or social means, Brooks also stresses her presence and power to compensate for the failure of both God and the social system. As an alternative, love of the mother replaces love of God as a source of salvation. The mother is, therefore, portrayed in these poems as a militant figure who seeks hatred, violence, and war in her fight for social justice. In "First Fight, Then Fiddle," Brooks describes how the mother Annie exhorts her children to give up fiddling for militant and social action. Urging her children to grapple for the immediate needs of black survival, Annie embodies the typical character of a racial mother who speaks for the collective needs of the black community:

But first to arms, to armor, carry hate

In front of you and harmony behind.

Be deaf to music and to beauty blind

Win war. Rise bloody, may be not too late

For having first to civilize a space

Wherein to play your violin with grace

(as cited in Finkleman, 2009, p. 288)

Against this background, Alice Walker strives to rescue black women from silence, to confront racism and sexism through the establishment of sisterhood and the revival of the American Southern experience, and to fight for a community and an identity. In view of these aims, Walker's writing demythologizes the damaging myths of black women, especially the powerful "Mammy figure." In doing so, she refers to the poet Jean Toomer who, in one of his paintings, qualified black women as "saints" for their intense spirituality. Toomer depicted their long history of mutilation, pain, and suffering to demonstrate how their bodies were transmuted into shrines and their minds into temples suitable for worship. Through analysis of this painting, Alice Walker advances the claim that these saints were without a doubt black women's mothers and grandmothers who lived lives of spiritual loss and agony so that the new generation of black women can inherit the vivid and creative spirit of "all mothers who were not famous."

Undertaking a large number of exhausting activities and responsibilities, Walker continues, mothers and grandmothers never sought to abandon their artistic genius. Walker also admits that she inherited her talent for writing stories from her mother and that she was guided by her bequest of love and beauty. To pay tribute to all black women of her mother's generation, she writes:

They were women then

My mamma's generation

Husky of voice-stout of

Step

With fists as well as

Hands

How they battered down

Doors

And ironed

Starched white

Shirts

How they led

Armies

Head ragged generals

Across mined

Fields

Booby-trapped

Kitchens

To discover books

Desks

A place for us

How they knew what we

Must know

Without knowing a page

Of it

Themselves. (as cited in Christian, 1994, pp. 48-49)

The concept of motherhood was also addressed by other renowned poets, including the South-African Nise Malange, who not only dramatizes her personal experience but also uses her poem as a pressing call for further involvement of African women to consider literary writing as an efficient weapon to achieve hypervisibility:

I am here dying of hunger

And my country is also dying

My children are too dying

Look at them:

How dull their eyes

How slow their walk and the turning

Of their heads

Nothing for them to eat

Can you hear?

They are crying. (as cited in Wisker, 2000, p. 176)

In view of the above discussion, it can be surmised that race, class, and gender subjection could not continue without ideological justifications that first emerged in the early period of slavery, but persisted through the pre-colonial and post-colonial era. Defying these controlling stereotypes of mothering and motherhood that aimed to obstruct the female 
social, political, and economic development constitutes a major concern for black feminist thought.

\section{The Assertion of Identity}

Colored people still face significant resistance and hostility due to the fact that Western culture is fostering such severances amongst these communities. Thus, the result of being separated from one's nation and roots, socialized as marginal and "othered" subjects, induces desperate need to belong, to be accepted, and to have roots. Yet, much of this has been shaped around feelings of self-hate nurtured from the early period of serfdom to that of neoclassicism. However, due to the influence of postmodernism, the notion of identity as a unitary and statistic trait is no longer accepted in feminist scholarship, since colored women's realities embrace a whole range of different identities and subjectivities, which are seen as constantly shifting, pluralistic, and dynamic aspects of relationships. Since race itself is a socially constructed identity, black personalities are engaged in a cultural hybridization through which conflicts and ambivalences play an active role in producing the "fractured self" in the context of a "norm-oriented" society.

In the process of becoming, celebrating differences provides a real stimulus to confirm a sense of identity rather than a reason for destruction. Writing is then seen as a historical act of recognizing one's roots and constructing one's identity. Drawing upon her experience of living in diaspora, the black British Caribbean poet Merle Collins (2002) explores issues of identity and resistance in many of her poems. Her "Chant Me a Tune," for instance, showcases the poet's psychological bifurcation towards her lost cultural heritage and the new culture acquired under colonialism. In this poem, under the incessant and unconscious pressure to remember her origins, the writer becomes disillusioned and nostalgic, as she attempts to balance her need for reintegration and self-discovery through the olden days, along with her acquaintance with British customs, which are juxtaposed to her refusal to uphold the so-called civility. Yet, the poet's ambivalence should not be interpreted as a cry of failure, but rather as a highly self-reflexive act, since the poet is aware of her own fractured psyche through which she can transcend time and seek the lost past to redeem the wretched present.

Similarly, Audre Lorde (1997) deploys the feeling of otherness that black women are experiencing when she addresses her "thin sister." Since skin color is a basic criterion according to which black women's identity is built, women of color tend to retreat into solitude and start a process of self-destruction because they do not conform to the physical norms established by the mainstream society. In "Song for a Thin Sister," Lorde pathetically reflects on her own disillusion with skin color, yet she ends the poem with a personal and encouraging message arguing that black skin is "always white." In other words, she rejects the fact that one's selfhood should be constructed upon such physical conditions, for there is no valuable rule asserting such founded biases:

I see your forever retreating

Shrinking to a stranger

In flight
Growing up

Black and fat

I was sure that skinny

Was funny or silly

But always

White. (p. 298)

While a large number of diasporic black female poets have implicitly exposed discomposure with their identities, others have explicitly asserted their own sense of comfort with their identities, origins, and skin color. Amongst them stands the activist Maud Sulter (1991) who perceives black women's creativity as a fundamental step toward self-definition. Sulter's "Poetics of a Family Tree" is a direct confrontation with the reader, who is urged to participate in the battle and reassert his/her social position as a full individual. The process of identity construction necessitates knowledge acquisition and willingness to compete with the white pre-established discourse. In the following lines of the poem, Sulter highlights the importance of education in achieving a reliable subjectivity:

Daughter, she cries

Learn the tongues

If this world voices

Teach the children

Of their wonder

Love as only a woman can

Take up the pen, the brush

Explosive

And name

Yes name

Yourself

Black

Women

Zami

Proud

Name yourself

Never forget

Our herstory. (p. 283)

In light of the facts already presented, it is evident that black identity construction is not a linear process, since it reflects a tableau of interwoven life experiences originating from different socio-historical epochs. Self-identity within this context denotes a continuous and constantly changing process of becoming, and the fracture of a dominant framing discourse in categorizing women of color as static subjects.

\section{CONCLUSION}

In summary, the arguments presented in this paper suggest that, under the triple milestone of gender, class, and race, women of color have experienced the most dehumanizing white patriarchal practices, which have denied their values, beliefs, and above all their dignity as human beings. In the same vein, the fashionable universality of "sisterhood" has solely accentuated their already disfavored situation, since it has erroneously defended the common distress inflicted upon these women. Moreover, the triple milestone has ignored the notion of difference as the basic argument on which black feminism is founded. 
It is equally important to note that poetic resistance and the very act of writing their experiences since the early decades of serfdom demonstrates black women's courage and willingness to move from silence, absence, and erasure to self-representation and the challenge of double dominant white mainstream discourse. For this purpose, colored women's literary realizations, and more specifically their poetry, have served as a platform from which female voices worldwide have attempted to break the boundaries that had silenced them for a long time.

As demonstrated in this paper, black women have long celebrated their identity, motherhood, and spirituality in the web of language, and have largely succeeded in their universal project to assert that a black woman's worth does not lie in established discourses, but in the everlasting gift of willingness and readiness to resist.

\section{REFERENCES}

Angelou, M. (2015). The Complete Poetry. New York, NY: Random House.

Armos, V., \& Pratibha, T. (2005). Challenging imperialism feminism. Feminist Review, 80, 44-63.

Best, E. (1992). The Wicked Sisters: Women Poets, Literary History and Discord. New York, NY: Oxford University Press.

Bethel, L. (1982). But some of us are brave. In G. T. Hull et al. (Eds.), All the women are white, all the Blacks are men, but some of us are brave : Black women's studies

Old Westbury, N.Y.: Feminist Press.

Brooks, G. (1945). A street in Bronzeville. New York and London: Harper \& Brothers.

Brooks, G. (1949). Annie Allen. New York, NY: Harper \& Brothers.

Brooks, G., \& Alexander, E. (2005). The essential Gwendolyn Brooks. New York, NY: Library of America.

Carretta, V. (Ed.) (2004). Unchained Voices: An Anthology of Black Authors. Lexington: University Press of Kentucky.

Collins, M. (2004). Chant me a tune. In D. Decaire (Ed.), Contemporary Caribbean Women's Poetry. New York, NY: Routledge.

Christian, B. T. (Ed.) (1994). Everyday Use. New Jersey, NJ: Rutgers University Press.

Davis, A. (1981). Women, Race and Class. New York, NY: Random House.

Davidson, C. N., \& Wagner Martin, L. (Eds.) (1995). The Oxford Companion to Women's Writing in the United States. New York, NY: Oxford University Press.

Fanon, F. (1952). Black Skin, White Masks. London, UK: Pluto Press.

Finkleman, P. (Ed.) (2009). Encyclopedia of African American History: 1896 to the Present. New York, NY: Oxford University Press.
Gargi, B. (1998). Tales of Dark-Skinned Women: Race, Gender and Global Culture. London, UK: UCL Press.

Gates, H. L. (Ed.) (1992). Contending Forces: A Romance Illustrative of Negro Life North and South. New York, NY: Oxford University Press.

Hayes, W. F. (Ed.) (2000). A Turbulent Voyage: Readings in African American Studies. Oxford, UK: Rowman \& Littlefield Publishers.

Hill, P. C. (2000). Black feminist thought: Knowledge, consciousness, and the politics of empowerment. New York, NY: Routledge.

Hurston, Z. N. (2008). Their Eyes Were Watching God. New York, NY: Harper Luxe.

Jacobs, H. (2013). The Norton Anthology of American Literature (shorter 8th ed., N. Baym \& R. S. Levine, eds.). New York, NY: W. W. Norton \& Company.

Lorde, A. (1997). The Collected Poems of Audre Lorde. New York, NY: W.W. Norton \& Harper.

Lorde, A. (2007). Sister Outsider: Essays and Speeches. Berkeley, CA: Crossing Press.

Marchand, M. H., \& Parpart, J. L. (Eds.) (1995). Feminism and Postmodernism Development. London, UK: Routledge.

Mirza, H. S. (Ed.) (1992). Black British Feminism. New York, NY: Routledge.

Mohanty, C. T. (2003). Cartographies of Struggle: Third World Women and the Politics of Feminism. Durham and London: Duke University Press.

Peterson, C. (1995). Doers of the World. New York, NY: Oxford University Press.

Powel, S. M. (2003). Spirituality: Redeeming Women Through Faith and Poetry. Retrieved July 21, 2019, from http://www.suite101.com

Purkayastha, D. (2012). Foregrounding 'her' stories: Black women's literary movement. Dibrugarh University Journal of English Studies, 20, 1-14.

Stanley, M. J., \& Ebna, B. A. (1994). Theorizing Black Feminism: The Visionary Pragmatism of Black Women. New York, NY: Busia.

Stasiulis, D. (1992). Theorizing Connections: Gender, Race, Ethnicity and Class, Race and Ethnic Relations in Canada. Toronto, Canada: Oxford University Press.

Suleri, S. (1992). Woman skin deep: Feminism and the postcolonial condition. Critical Inquiry, 18(4), 756-769.

Sulter, M. (1991). Echo: Works by Women Artists, 18501940. Liverpool, UK: Tate Gallery.

Urubshurow, V. K. (2008). Introducing World Religions (Uma Chakravarti and Kumkum Roy, trans.). New York, NY: Routledge.

Walker, A. (1983). In Search of Our Mother's Gardens: Womanist Prose. San Diego, CA: Harcourt Brace Jovanovich.

Wisker, G. (Ed.) (2000). Post-Colonialism and African Women's Writing. London, UK: MacMillan Press. 